Jurnal Neutrino Vol. 3, No. 2, April 2011

\title{
UJI KALOR BAKAR BAHAN BAKAR CAMPURAN BIOETANOL DAN MINYAK GORENG BEKAS
}

\author{
Imam Tazi ${ }^{1}$, Sulistiana ${ }^{2}$
}

\begin{abstract}
ABSTRAK:Menurut laporan The World Energy Council tahun 1993, menjelang tahun 2020 kebutuhan energi dunia akan meningkat dari 8,8 Gtoe (gigatons of oil equivalent) menjadi 11,3 sampai 17,2 Gtoe (IEA, 2006). Kondisi tersebut akan menguras banyak cadangan minyak bumi. Bietanol adalah salah satu sumber energi alternatif baru. Tujuan khusus dari penelitian ini adalah mengetahui besar kalor yang dihasilkan oleh bahan bakar tersebut,mengetahui komposisi campuran bioetanol dan minyak goreng bekas yang dapat digunakan sebagai bahan bakar kompor bertekanan. Hasil dari penelitian uji kalor bakar bahan bakar campuran bioetanol dan minyak goreng bekas untuk nilai kalornya adalah 76,86 J/kg - 27,52J/kg, sedangkan nilai viskositasnya 46,5 cSt - 22,5 cSt. Hasil dari penelitian ini menunjukkan untuk nilai kalor yang tepat dijadikan sebagai bahan bakar kompor bertekanan apabila campuran bioetanol lebih banyak dari pada minyak goreng bekas. Kesimpulan dari penelitian ini adalah bahwa besar nilai kalor yang dihasilkan oleh bahan bakar campuran bioetanol dan minyak goreng bekas adalah 76,86 J/kg dengan viskositasnya 46,2 cSt. Sedangkan nilai kalor bakar terendah adalah $27,52 \mathrm{~J} / \mathrm{kg}$ dengan viskositasnya 22,5 cSt. Bertambahnya campuran akan mempengaruhi penurunan nilai kalor bakar campuran bioetanol. Komposisi campuran bioetanol dan minyak goreng bekas yang dapat digunakan sebagai bahan bakar pada kompor bertekanan apabila penambahan campuran bioetanol lebih banyak dari minyak goreng bekas.
\end{abstract}

Kata Kunci : Kalor bakar, Bioetanol, dan Calorimeter Bomb.

\section{PENDAHULUAN}

Menurut laporan The World Energy Council tahun 1993, menjelang tahun 2020 kebutuhan energi dunia akan meningkat dari 8,8 Gtoe (gigatons of oil equivalent) menjadi 11,3 sampai 17,2 Gtoe (IEA, 2006). Kondisi tersebut akan menguras banyak cadangan minyak bumi. Berdasarkan perkiraan, minyak bumi Indonesia hanya bertahan dalam kurun waktu kurang dari 20 tahun lagi. Kondisi demikian memicu terjadinya krisis energi (cadangan minyak) di Indonesia(Dasuki, 2000).

Sudah saatnya Indonesia mengurangi ketergantungan terhadap bahan bakar fosil dengan mengembangkan sumber energi alternatif baru. Salah satu solusinya adalah bioenergi lebih spesifiknya biofuel Bahan Bakar Nabati (BBN) karena Indonesia sangat kaya akan sumber daya alam berupa biomassa yang dapat dimanfaatkan sebagai bahan baku bioenergi.

Bioetanol adalah salah satu bahan bakar nabati yang dapat dihasilkan dari tumbuhan. Pada prinsipnya pembuatan bioetanol yaitu melalui proses fermentasi untuk memecah protein dan destilasi atau penyulingan yang relatif mudah sehingga gampang diterapkan. Sedangkan minyak goreng bekas juga merupakan bahan bakar nabati yang dapat dihasilkan dari kelapa sawit. Selama ini minyak goreng bekas merupakan limbah

1 and 2 Jurusan Fisika Fakultas Sains dan Teknologi UIN Maulana Malik Ibrahim Malang 
bagi ibu rumah tangga, bahkan dibuang sembarangan. Jadi baik Bioetanol maupun minyak goreng bekas mempunyai nilai ekonomis yang sangat tinggi jika dapat digunakan sebagai bahan bakar.

Saleha (2008), pada studi pengaruh pencampuran bioetanol dengan bensin terhadap karakteristik fisika menyebutkan bahwa pencampuran bioetanol dengan bensin dapat digunakan untuk bahan bakar mesin asal diperhatikan korositas dari mesin. Rahardjo (2009), pada pemanfaatan oli bekas dengan pencampuran bioetanol sebagai bahan bakar pada atomizing burner didapatkan bahwa kadar campuran bioetanol yang semakin tinggi akan menurunkan viskositas serta nilai kalor bahan bakar.

Berdasarkan latar belakang diatas maka peneliti melakukan penelitian UJI KALOR BAKAR BAHAN BAKAR CAMPURAN BIOETANOL DAN MINYAK GORENG BEKAS dengan komposisi tertentu sehingga mempunyai sifat nilai bakar, dan viscositas yang sama dengan minyak tanah atau bahkan bisa lebih baik, sehingga bisa menghasilkan suatu produk yang dijadikan sebagai sumber energi alternatif baru yang praktis, aman, dan tepat untuk diterapkan pada skala rumah tangga.

\section{KAJIAN TEORI \\ Bioetanol}

Bio-etanol merupakan salah satu jenis biofuel (bahan bakar cair dari pengolahan tumbuhan) di samping Biodiesel. Bio-etanol adalah etanol yang dihasilkan dari fermentasi glukosa (gula) yang dilanjutkan dengan proses destilasi. Proses destilasi dapat menghasilkan etanol dengan kadar 95\% volume, untuk digunakan sebagai bahan bakar (biofuel) perlu lebih dimurnikan lagi hingga mencapai $99 \%$ yang lazim disebut fuel grade ethanol (FGE). Proses pemurnian dengan prinsip dehidrasi umumnya dilakukan dengan metode Molecular Sieve, untuk memisahkan air dari senyawa etanol. Bahan baku bio-etanol yang dapat digunakan antara lain ubi kayu, tebu, sagu dll (Vivandra, Dkk, 2009).

\section{Produksi Bioetanol}

Secara umum, proses pengolahan bahan berpati seperti ubi kayu, jagung dan sagu untuk menghasilkan bio-etanol dilakukan dengan proses urutan. Pertama adalah proses hidrolisis, yakni proses konversi pati menjadi glukosa. Pati merupakan homopolimer glukosa dengan ikatan $\alpha$-glikosidik. Pati terdiri dari dua fraksi yang dapat dipisahkan dengan air panas, fraksi terlarut disebut amilosa dan fraksi tidak terlarut disebut amilopektin. Amilosa mempunyai struktur lurus dengan ikatan $\alpha$-(1,4)-D-glikosidik sedangkan amilopektin mempunyai struktur bercabang dengan ikatan a-(1,6)-Dglikosidik sebanyak $4-5 \%$ dari berat total.

\section{Minyak Goreng}

Minyak goreng adalah minyak nabati yang telah dimurnikan dan dapat digunakan sebagai bahan pangan. Minyak goreng yang baik mempunyai sifat tahan panas, tidak 
merusak hasil gorengan, menghasilkan gorengan dengan tekstur dan rasa yang bagus, asapnya sedikit setelah digunakan berulang-ulang, serta menghasilkan warna keemasan pada produk ( Ketaren, 1986). Pertumbuhan jumlah penduduk dan perkembangan industri, restoran dan usaha fastfood yang menyebabkan dihasilkanya minyak goreng bekas dalam jumlah yang cukup tinggi. apabila minyak goreng bekas tersebut dibuang sangatlah tidak efisien dan mencemari lingkungan. Karena itu minyak goreng bekas dapat dimanfaatkan sebagai bahan bakar campuran bioetanol.

\section{Minyak Goreng Bekas}

Selama penggorengan, minyak goreng akan mengalami pemanasan pada suhu tinggi $170^{\circ} \mathrm{C}-180^{\circ} \mathrm{C}$ dalam waktu yang cukup lama. Hal ini akan menyebabkan terjadinya proses oksidasi, hidrolisis dan polimerisasi yang menghasilkan senyawasenyawa hasil degradasi minyak keton, aldehid dan polimer yang merugikan kesehatan manusia. Proses-proses tersebut menyebabkan minyak mengalami kerusakan. Kerusakan utama timbulnya bau dan rasa tengik, sedangkan kerusakan lain meliputi peningkatan kadar asam lemak bebas (FFA), bilangan Iodin (IV), timbulnya kekentalan minyak, terbentuknya busa, adanya kotoran dari bumbu yang digunakan dan bahaya yang di goreng ( Ketaren, 1986).

\section{Sifat Fisika Minyak Goreng Bekas}

Penggunaan minyak jelantah secara berulang-ulang akan mengubah warna minyak menjadi lebih gelap, pembentukan busa, timbul bau tengik, serta peningkatan viskositas dan massa jenis minyak.

\section{Sifat Kimia Minyak Goreng Bekas}

Pemanasan dan penggunaan minyak jelantah yang berulang-ulang akan mengubah komposisi kimiawi dari minyak goreng. Perubahan ini dapat disebabkan proses oksidasi, polimerisasi, hidrolisis dan karamelisasi yang terjadi di dalamnya.

\section{Nilai Kalor}

Nilai kalor atau heating velue adalah jumlah energi yang dilepaskan pada proses pembakaran persatuan volume atau persatuan massanya. Nilai kalor bahan bakar menentukan jumlah konsumsi bahan bakar tiap satuan waktu. Makin tinggi nilai kalor bahan bakar menunjukkan bahan bakar tersebut semakin sedikit pemakaian bahan bakar. Nilai kalor bahan bakar ditentukan berdasarkan hasil pengukuran dengan kalorimeter dilakukan dengan membakar bahan bakar dan udara pada temperatur normal, sementara itu dilakukan pengukuran jumlah kalor yang terjadi sampai temperatur dari gas hasil pembakaran turun kembali ketemperatur normal. 


\section{Kalor}

Jika benda menerima kalor, maka kalor itu digunakannya untuk menaikkan suhu benda, atau berubah wujud. Benda yang berubah wujud dapat berubah wujud dapat berupa mencair, atau menguap. Pada penelitian ini kalor hasil pembakaran sempurna disebut sebagai kalor bakar. Perubahan kalor pada suatu reaksi dapat diukur melalui pengukuran perubahan suhu yang terjadi pada reaksi tersebut. Persamaanya sebagai berikut :

$$
\begin{aligned}
\mathrm{q}=m \times \mathrm{c} \times & \Delta \mathrm{T} \\
\mathrm{q}_{\text {kalorimeter }}=\mathrm{C} \times \Delta \mathrm{T} & \\
\text { dimana } \mathrm{q} & =\text { jumlah kalor }(\mathrm{J}) \\
m & =\text { massa zat }(\mathrm{g}) \\
\Delta \mathrm{T} & =\text { perubahan suhu }\left({ }^{\circ} \mathrm{C} / \mathrm{K}\right) \\
\mathrm{C} \quad & =\text { kalor jenis }\left(\mathrm{J} / \mathrm{g} \cdot{ }^{\circ} \mathrm{C}\right) \\
\mathrm{C} & =\text { kapasitas kalor }\left(\mathrm{J} /{ }^{\circ} \mathrm{C}\right)
\end{aligned}
$$

( Brady, James E. 1999)

\section{Kalorimeter Bomb}

Kalorimeter bom adalah alat yang digunakan untuk mengukur jumlah kalor (nilai kalori) yang dibebaskan pada pembakaran sempurna (dalam O2 berlebih) suatu senyawa, bahan makanan, bahan bakar atau khusus digunakan untuk menentukan kalor dari reaksi-reaksi pembakaran.

Reaksi pembakaran yang terjadi di dalam bom, akan menghasilkan kalor dan diserap oleh air dan bom. Oleh karena tidak ada kalor yang terbuang ke lingkungan, maka:

$\mathrm{q}_{\text {reaksi }}=-\left(\mathrm{q}_{\mathrm{air}}+\mathrm{q}_{\mathrm{bom}}\right)$

Jumlah kalor yang diserap oleh air dapat dihitung dengan rumus :

qair $\quad=\mathrm{m} \times \mathrm{c} \times \Delta \mathrm{T}$

dengan :

$\mathrm{m}=$ massa air dalam kalorimeter $(\mathrm{g})$

$\mathrm{c}=$ kalor jenis air dalam kalorimeter $\left(\mathrm{J} / \mathrm{kg}{ }^{\circ} \mathrm{C}\right)$ atau $(\mathrm{J} / \mathrm{kg} . \mathrm{K})$

$\Delta \mathrm{T}=$ perubahan suhu $\left({ }^{\circ} \mathrm{C}\right.$ atau $\left.\mathrm{K}\right)$.

Jumlah kalor yang diserap oleh bom dapat dihitung dengan rumus :

$\mathrm{q}_{\mathrm{bom}}=\mathrm{C}_{\mathrm{bom}} \times \Delta \mathrm{T}$

dengan :

$\mathrm{C}_{\mathrm{bom}}=$ kapasitas kalor bomb $\left(\mathrm{J} / \mathrm{g}{ }^{\circ} \mathrm{C}\right)$ atau $(\mathrm{J} / \mathrm{K})$

$\Delta \mathrm{T}=$ perubahan suhu $\left({ }^{\circ} \mathrm{C}\right.$ atau $\left.\mathrm{K}\right)$. 


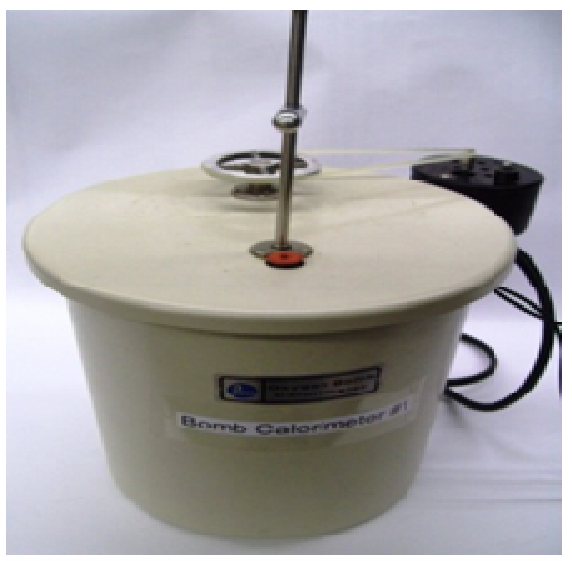

Gambar 1. Kalorimeter Bomb

\section{Viskositas}

Viskositas merupakan ukuran kekentalan fluida yang menyatakan besar kecilnya gesekan dalam fluida. Semakin besar viskositas fluida, maka semakin sulit suatu fluida untuk mengalir dan juga menunjukkan semakin sulit suatu benda bergerak didalam fluida tersebut. Didalam zat cair, viskositas dihasilkan oleh gaya kohesi antara molekul zat cair. (Massey, BS. 1983).

Secara matematis persamaan umum viskositas dapat ditulis :

$F=\eta A \frac{V}{l}$

Dimana

$\mathrm{F}$ = gaya pada permukaan zat cair $(\mathrm{N})$

$\eta=$ koefisien viskositas fluida $\left(\mathrm{N} \mathrm{s} / \mathrm{m}^{2}\right)$

$\mathrm{A}=$ luas cairan $\left(\mathrm{m}^{2}\right)$

$\mathrm{V}=$ kecepatan dinding yang bergerak $(\mathrm{m} / \mathrm{s})$

$\mathrm{L}=$ jarak kedua permukaan $(\mathrm{m})$

\section{METODE PENELITIAN}

\section{Waktu dan Tempat Penelitian.}

Penelitian ini dilakukan pada bulan September - Nofember 2010 di laboratorium Termodinamika jurusan Fisika Universitas Islam Negeri Maulana Malik Ibrahim Malang dan Laboratorium Nutrisi Makanan dan Ternak jurusan Nutrisi dan Makanan Ternak Universitas Brawijaya Malang. 
Alat dan Bahan

\begin{tabular}{|c|l|l|c|}
\hline No. & \multicolumn{1}{|c|}{ Nama } & \multicolumn{1}{|c|}{ Spesifikasi } & Jumlah \\
\hline \hline 1 & Calorimeter bomb & Adiabatik & 1 \\
\hline 2 & Beaker glass & -Duran 250 ml & 2 \\
& & -Duran 1000 ml & 3 \\
\hline 3 & Rotary Viscometer & LV series & 1 \\
\hline 4 & Tabung Bahan Bakar & - & 1 \\
\hline 5 & Pompa Angin & - & 1 \\
\hline 6 & Selang & - & 1 \\
\hline 7 & Spuyer & - & 1 \\
\hline 8 & Saringan & - & 1 \\
\hline 9 & Pengaduk Batang Magnetik & - & 1 \\
\hline
\end{tabular}

Bahan yang dibutuhkan pada penelitian

1. Minyak Goreng Bekas

2. Bioetanol $96 \%$.

\section{Langkah-Langkah Penelitian}

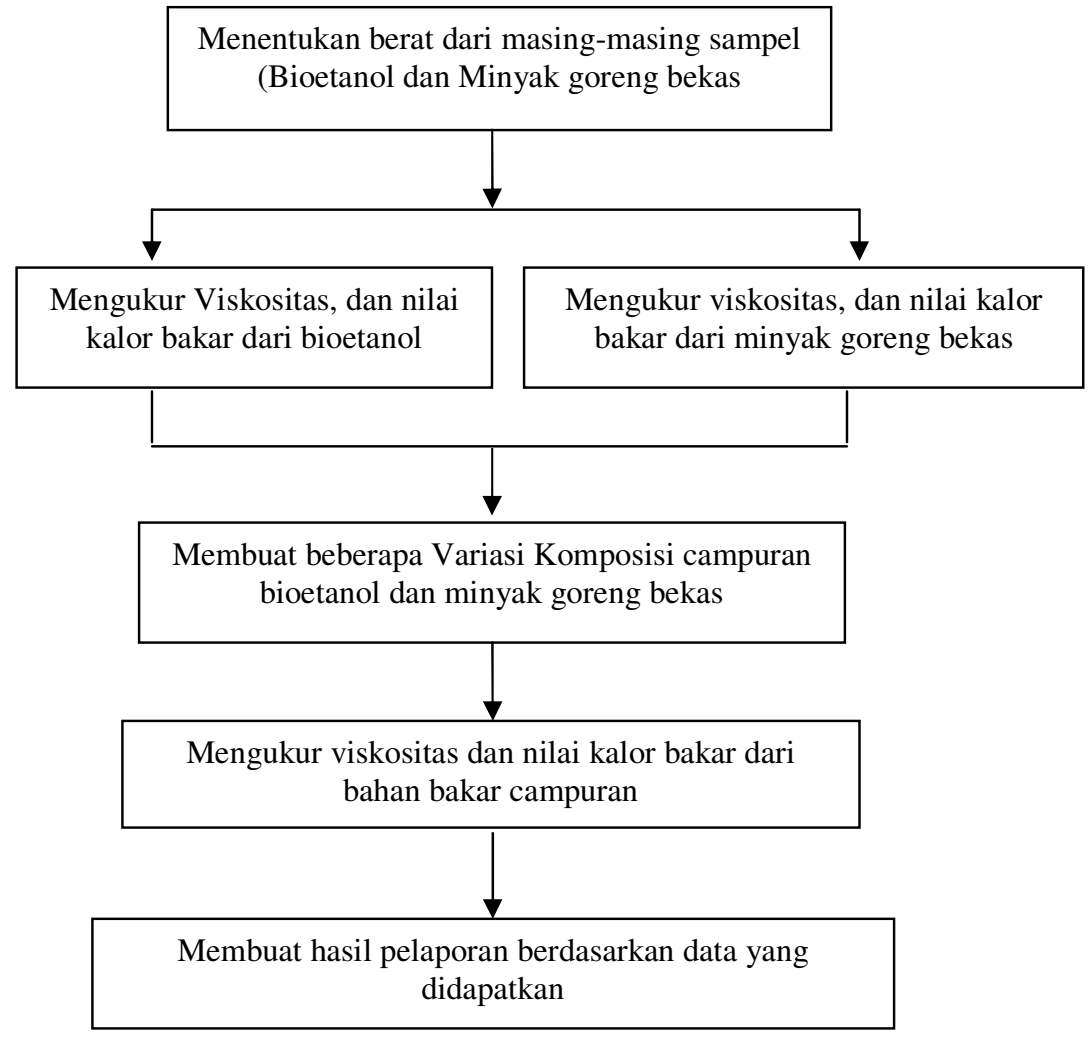

Gambar 2. Diagram blok uji kalor bahan bakar campuran bioetanol dan minyak goreng bekas. 
Berikut keterangan dari diagram blok :

a. Menentukan berat dari masing-masing sampel yaitu bioetanol dan minyak goreng bekas sesuai yang dibutuhkan.

b. Mengukur viskositas, dan nilai kalor bakar dari bioetanol yang dihasilkan.

c. Mengukur viskositas, dan nilai kalor bakar dari minyak goreng bekas

d. Melakukan pencampuran dengan variasi komposisi dari campuran bioetanol dan minyak goreng bekas.

e. Mengukur viskositas, dan nilai bakar dari hasil campuran.

f. Menguji kompor dengan bahan bakar campuran bioetanol dan minyak goreng bekas dengan uji besar kalor yang dihasilkan.

g. Membuat pelaporan.

\section{Sampel Penelitian}

Bioetanol yang tersedia adalah 1 liter, maka dibuat total sembilan percobaan dan setiap satu sampel campuran jumlah totalnya adalah $100 \mathrm{ml}$, maka komposisi campuran bahan bakar bioetanol dan minyak goreng bekas dapat dilihat pada tabel 3.2 sebagai berikut :

\begin{tabular}{|l|c|c|}
\hline No & Bioetanol (ml) & Minyak goreng bekas (ml) \\
\hline 1 & 10 & 90 \\
\hline 2 & 20 & 80 \\
\hline 3 & 30 & 70 \\
\hline 4 & 40 & 60 \\
\hline 5 & 50 & 50 \\
\hline 6 & 60 & 40 \\
\hline 7 & 70 & 30 \\
\hline 8 & 80 & 20 \\
\hline 9 & 90 & 10 \\
\hline
\end{tabular}

Pengujian Nilai Kalor Bakar dan Viskositas Campuran Bioetanol dan Minyak Goreng Bekas Pengujian Nilai Kalor Bakar

1. Bersihkan tabung bom dari sisa pengujian sebelumnya. 
2. Timbang bahan bakar (sampel) yang akan diukur dengan timbangan, sebesar 1 gram.

3. Siapkan kawat untuk penyala dengan menggulungnya dan memasangnya pada tangkai penyala yang terpasang pada penutup bomb.

4. Tempatkan cawan berisi bahan bakar pada ujung tangkai penyala.

5. Tutup bomb dengan kuat setelah dipasang ring - $\mathrm{O}$ dengan memutar penutup tersebut.

6. Isikan oksigen kedalam bomb dengan tekanan 15-20 bar.

7. Tempatkan bomb yang telah terpasang didalam kalorimeter.

8. Masukkan air pendingin sebanyak $1250 \mathrm{ml}$.

9. Tutup kalorimeter dengan alat penutupnya

10. Hidupkan pengaduk air pendingin selama 5 (lima) menit sebelum penyalaan dilakukan

11. Baca dan catat temperatur air pendingin.

12. Hidupkan penyalaan, gunakan tombol yang paling kanan

13. Air pendingin terus diaduk selama selama 5 (lima) menit setelah penyalaan berlangsung.

14. Baca dan catat kembali temperatur air pendingin.

15. Matikan pengaduk.

16. Peralatan disiapkan kembali untuk pengujian berikutnya.

17. Lakukan pengukuran untuk suatu bahan bakar yang diuji/ diukur.

\section{Pengujian Pengukuran viskositas}

Pengukuran viskositas yaitu dengan menggunakan Rotary viscometer yang harus disesuaikan sampai jarum menunjuk pada skala nol.

\section{HASIL DAN PEMBAHASAN}

\section{Hasil Pengujian Nilai Kalor Bakar Campuran Bioetanol dan Minyak Goreng Bekas}

Tabel 4.1 nilai kalor bakar komposisi campuran bioetanol dan minyak goreng bekas

\begin{tabular}{|c|c|c|c|c|c|c|}
\hline \multicolumn{5}{|c|}{ Perbandingan Bahan Bakar Campuran } & \multirow[b]{2}{*}{$\underset{\mathrm{D}}{\Delta \mathrm{T} \mathrm{C}^{\circ} \mathrm{C}}$} & \multirow[b]{2}{*}{$\frac{\text { Nilai }}{\text { Kalar }}$} \\
\hline No & $\begin{array}{c}\% \\
\text { bioetanol }\end{array}$ & $\begin{array}{c}\% \\
\text { Minyal } \\
\text { goreng } \\
\text { bekas } \\
\text { (m1) }\end{array}$ & $\mathrm{I} 1\left({ }^{\circ} \mathrm{C}\right)$ & $\mathrm{T} 2\left({ }^{\circ} \mathrm{C}\right)$ & & \\
\hline 1 & 10 & 90 & 33.47 & 37.18 & 3.71 & 76.86 \\
\hline 2 & 20 & 80 & 30.92 & 34.54 & 3.62 & 70.16 \\
\hline 3 & 30 & 70 & 32.26 & 35.43 & 3.17 & 67.24 \\
\hline 4 & 40 & 60 & 35.57 & 38.57 & 3 & 63.27 \\
\hline 5 & 50 & 50 & 34.01 & 34.71 & 2.3 & 47.46 \\
\hline 6 & 60 & 40 & 34.73 & 36.92 & 2.19 & 46.48 \\
\hline 7 & 70 & 30 & 33.97 & 36.13 & 2.16 & 44.63 \\
\hline 8 & 80 & 20 & 37.61 & 39.72 & 2.11 & 43.14 \\
\hline 9 & 90 & 10 & 33.83 & 35.21 & 1.38 & 27.52 \\
\hline
\end{tabular}


Grafik hubungan antara campuran bahan (bakar bioetanol dan minyak goreng bekas) dan nilai kalor

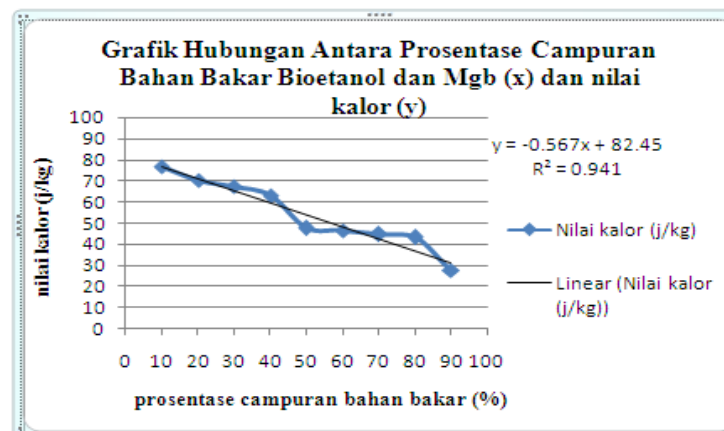

Gambar 4.1 Grafik hubungan antara campuran bahan bakar (bioetanol dan minyak goreng bekas) dan nilai bakar.

\section{Hasil Pengujian Viskositas Campuran Bioetanol Dengan Minyak Goreng Bekas}

Tabel 4.2 Hubungan antara komposisi campuran bahan bakar (Bioetanol dan minyak goreng bekas) dengan viskositas

\begin{tabular}{|c|c|c|c|}
\hline \multicolumn{3}{|c|}{$\begin{array}{c}\text { Perbandingan Bahan Bakar } \\
\text { Campuran }\end{array}$} & \multirow[b]{2}{*}{$\frac{\text { Viskositas }}{(c S t)}$} \\
\hline No & $\begin{array}{c}\% \\
\text { bioetano1 }\end{array}$ & $\begin{array}{l}\text { \% Minyak } \\
\text { goreng } \\
\text { bekas }\end{array}$ & \\
\hline 1 & 10 & 90 & 46.2 \\
\hline 2 & 20 & 80 & 44.7 \\
\hline 3 & 30 & 70 & 43.3 \\
\hline 4 & 40 & 60 & 42.5 \\
\hline 5 & 50 & 50 & $4 \mathrm{O}_{-} 1$ \\
\hline 6 & 60 & 40 & 32.2 \\
\hline 7 & 70 & 30 & 30.1 \\
\hline 8 & 80 & 20 & 26.3 \\
\hline 9 & 90 & 10 & 22.5 \\
\hline
\end{tabular}

Grafik hubungan prosentase campuran bahan bakar ( bioetanol dan minyak goreng bekas) dan Viskositas

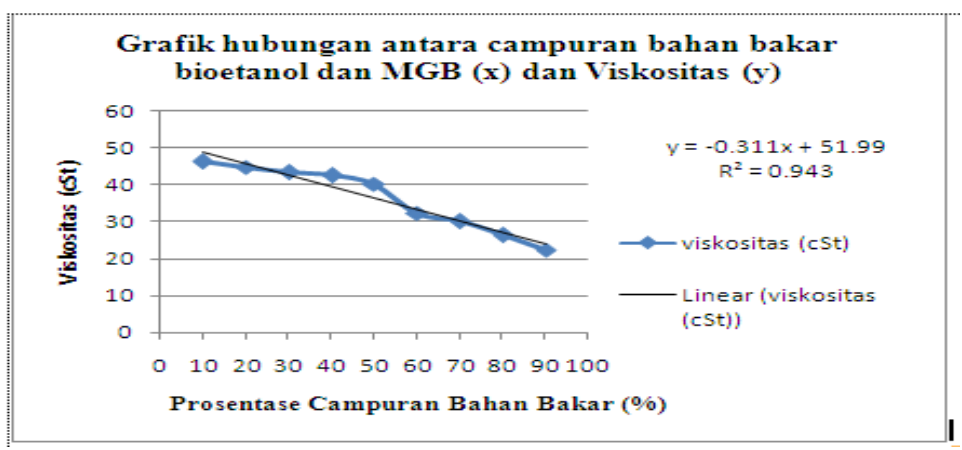

Gambar 4.2 Grafik hubungan prosentase campuran (bioetanol dan minyak goreng bekas) dan viskositas 
Analisa Pembahasan

\section{Pengujian Nilai Kalor Bahan Bakar Campuran Bioetanol dan Minyak Goreng Bekas}

Berdasarkan hasil nilai kalor bakar dari komposisi kedua bahan bakar campuran bioetanol dan minyak goreng bekas, jika semakin banyak penambahan campuran bioetanol maka semakin rendah nilai kalor bakar campuran bioetanol. Nilai kalor bakar menunjukkan kalor yang dihasilkan dari pembakaran bahan bakar. Jika dalam pembakaran yang sempurna, bahan bakar akan terbakar seluruhnya menjadi energi panas. Dari tabel 4.1 dapat dilihat bahwa penambahan campuran bioetanol dapat menurunkan nilai kalor bakar campuran bioetanol jika campuran minyak gorengnya lebih sedikit dari bioetanolnya. Apabila campuran minyak goreng tersebut lebih banyak dari bioetanol maka nilai kalor campuran dari kedua bahan bakar bioetanol dan minyak goreng bekas akan semakin tinggi. Jadi, semakin banyak penambahan bioetanol kedalam minyak goreng bekas maka campuran bahan bakar akan semakin mudah mengalami proses penguapan pada kompor bertekanan. Dari data hasil penelitian nilai kalor bakar dari minyak goreng bekas adalah 91,98 J/ kg sedangkan bioetanol adalah $62.39 \mathrm{~J} / \mathrm{kg}$. Sedangkan nilai bahan bakar campuran nilai kalor tertinggi adalah 76,86 $\mathrm{J} / \mathrm{kg}$ dan nilai kalor terendah adalah $27,52 \mathrm{~J} / \mathrm{kg}$. berdasarkan hasil tersebut nilai kalor bakar menentukan jumlah konsumsi bahan bakar tiap satuan waktu.

\section{Pengujian Viskositas Campuran Bioetanol dan Minyak goreng bekas.}

Gambar grafik (4.2) diatas menunjukkan grafik hubungan viskositas terhadap komposisi campuran bioetanol dan minyak goreng bekas, pada grafik diatas terlihat hubungan yang linear dimana semakin banyak komposisi minyak goreng bekas dalam campuran semakin tinggi viskositasnya. Viskositas bahan bakar cair merupakan karakteristik yang paling penting dalam penggunaan dan penyimpanan bahan bakar. Jika viskositas terlalu tinggi maka bahan bakar akan sulit dalam pemompaan, dan pengkabutan. Viskositas akan mempengaruhi proses pengkabutan, yaitu semakin rendah viskositasnya maka bahan bakar akan lebih mudah dikabutkan. Jika bahan bakar mudah dikabutkan maka bahan bakar akan lebih mudah dalam penyalaanya dan semakin banyak bahan bakar yang terbakar sempurna sehingga temperatur yang dihasilkanpun akan semakin tinggi . Pada uji viskositas minyak goreng bekas nilai viskositasnya 60 (cSt) sedangkan untuk bioetanol nilai viskositasnya 1 (cSt). Dari tabel diatas dapat dilihat bahwa secara umum viskositas bahan bakar komposisi campuran bioetanol dan minyak goreng bekas semakin menurun seiring dengan penambahan ukuran bioetanol. Hal ini dipengaruhi oleh viskositas bioetanol dimana viskositas bioetanol lebih rendah dibandingkan dengan viskositas minyak goreng bekas. Sehingga semakin banyak penambahan bioetanol yang dicampurkan maka semakin rendah viskositas bahan bakar yang dihasilkan. Dalam pengujian viskositas komposisi campuran kedua bahan bakar dipengaruhi oleh banyak sedikitnya minyak goreng bekas yang dipakai selama pengujian viskositasnya berlangsung. Dari data tabel hasil uji viskositas komposisi 
campuran kedua bahan bakar tertinggi adalah 46,20 cSt dan terendah 22,50 cSt. Pada pembakaran jika viskositas suatu bahan bakar terlalu tinggi, maka hasil yang didapatkan dari pembakaran tersebut tidak akan maksimal sehingga pemakaianya dalam kompor bertekanan menggunakan viskositas yang nilai viskositasnya paling rendah dimana campuran bioetanolnya lebih tinggi daripada minyak goreng bekas. Tujuan dilakukan ini agar mendapatkan kalor dan nyala api yang maksimal dalam pemakaian pada kompor bertekanan.

\section{KESIMPULAN}

Berdasarkan dari analisa hasil penelitian serta pembahasan yang telah dilakukan dapat disimpulkan sebagai berikut :

1. Besar nilai kalor bakar yang dihasilkan oleh bahan bakar campuran bioetanol dan minyak goreng bekas adalah 76,86 J/kg dengan nilai viskositasnya 46,2 cSt. Sedangkan nilai kalor bakar terendah adalah 27,52 J/kg dengan viskositasnya 22,5 cSt. Bertambahnya campuran bioetanol kedalam bahan bakar campuran akan mempengaruhi penurunan nilai kalor bakar campuran bioetanol.

2. Komposisi campuran bioetanol dan minyak goreng bekas yang dapat digunakan sebagai bahan bakar pada kompor bertekanan apabila penambahan campuran bioetanol lebih banyak dari minyak goreng bakar

\section{SARAN}

1. Agar penelitian ini lebih efektif dan efisien hendaknya parameter fisika yang digunakan yaitu dalam pengukuran campuran bioetanol dan minyak goreng bekas dengan mencari titik nyalanya, densitas, dan titik asap.

2. Minyak goreng bekas yang digunakan hendaknya diolah terlebih dahulu untuk meminimalisir residu dari minyak goreng bekas yang menyebabkan terhambatnya bahan bakar saat mengalami proses pembakaran pada kompor bertekanan.

\section{DAFTAR PUSTAKA}

Abdullah, M. 2005. Respon Rakyat Atas Krisis Energi. http: //www.Respon_Rakyat Atas Krisis Energi. Com. Diakses tanggal 09 -Mei -2010.

Abdushshamad, M. 2003. Mukjizat Ilmiah dalam Al Qur'an. Jakarta: Akbar Medika Eka Sarana..

Brady, James E. 1999. Kimia Universitas Azas dan Struktur Jilid I Edisi ke-5. Jakarta : Bina Rupa Aksara.

Dasuki AS. 2000. Cadangan Energi, Kebutuhan Energi, dan Teknologi Masa Depan. Makalah diskusi seharian dalam bidang teknologi masa depan yang ramah lingkungan : Jakarta. 
Giancoli, D.C. 1998. Fisika Jilid I Edisi ke-5. Jakarta : Erlangga.

Ketaren, S. 1986. Minyak dan Lemak Pangan. Jakarta : UI Press.

Kleinfelter, Wood. 1989. Kimia Untuk Universitas Jilid I. Jakarta : Erlangga.

Luciana B, Dkk. 2005. Minyak Gorengpun Bisa Melawan Kolesterol. Jakarta : Erlangga.

Massey, BS. 1983. Mechanic of Fluids fifth Edition. Terjemahan dari http:// id. Wikipedia

Rahardjo, W. 2009. Pemanfaatan oli bekas dengan pencampuran bioetanol sebagai bahan bakar pada atomizing burner. Surakarta : Univeritas Sebelas Maret Surakarta.

Saleha, S. 2007. Studi pengaruh pencampuran bioetanol dengan solar terhadap karakteristik fisika. Sumatra Utara

Shihab, Q. 2002. Tafsir Al Misbah: Pesan, Kesan dan Keserasian Al Qur'an. Jakarta: Lentera Hati.. Rahardjo, W. 2009. Pemanfaatan oli bekas dengan pencampuran bioetanol sebagai bahan bakar pada atomizing burner. Surakarta : Univeritas Sebelas Maret Surakarta.

Vivandra, Dkk. 2009. Bioetanol Gel ubi jalar produk inovatif sebagai sumber energi alternative pada sector rumah tangga. Bogor : Institut Pertanian Bogor.

Widayat, L. 2009. Pembuatan biodiesel dari minyak goreng bekas dengan proses CATALYTIC CRACKING, Semarang : Universitas Diponegoro. 